\title{
Liminality, Lim, Mobility and Memory. Disrupting the Nature of Things, Beings and Becomings
}

\author{
Sangeeta Bagga-Gupta \\ Professor of Education with a multidisciplinary background, School of \\ Language and Communication, Jönköping University, Jönköping, Sweden \\ sangeeta.bagga-gupta@ju.se

\section{Machunwangliu Kamei} \\ Assistant professor, Department of Media Studies, svKM's UPG College, \\ Mumbai, India \\ kameimachun@gmail.com
}

\begin{abstract}
Engaging with four geopolitical timespaces, and the concepts of liminality, lim/lines/ borders/boundaries, mobility and memory, against the backdrop of pre-, anti-, postand de-colonial ideas, this study illustrates how tenets of what we call a "Second Wave of Southern Perspectives" (SWaSP) can illuminate the myths and imaginations that continue to give credibility to the idea of bounded language, identity and nation-states, including the role of languaging as constitutive dimension of these processes. The study presented in this paper has two aims. First, it explicates a SWaSP framing wherein the role of languaging is both a key dimension of the (multi-scalar) organization of everyday life inside and outside institutional physical-digital spaces, and of the remembering of lim i.e., lines or boundaries as dimensions of belonging. Second, by juxtaposing ideas about belonging and (shifting) boundaries across time and spaces, it highlights the mechanisms involved in contemporary re-enforcements of archaic conceptualizations of language, identity and nation-spaces across global settings. We argue that these mechanisms constitute a similar endeavor across the global-North/ South, not least given recent discussions related to mobility and digitalization more generally wherein issues regarding democracy and equity are increasingly confronted with rising right-wing agendas and a racial renaissance. We attempt to show how identity tensions of "individuals/communities" and "an-other" are co-construed and argue that such processes contribute to the re-enforcing naturalization of archaic
\end{abstract}


conceptualizations pertaining to not only language, identity, nation-spaces, but also nationalism.

\section{Keywords}

languaging - liminality - boundaries - margins - mobility - memory

\section{Introduction}

Conceptualizations regarding the boundary-marked nature of language, human identity, and nation-spaces (and their populations) appear etched in scholarship despite having been challenged through historical, philosophical, and empirical explorations. In addition to the fallacies (that have been debunked in some scientific quarters) pertaining to monolingualism, monoethnicities, singular-trait based human identities and monoculturally shaped human collectives that populate (or until recently were seen as populating) nation-spaces, it has also become increasingly clear that the creation of these entities takes place through naming practices (Bagga-Gupta 2018, forthcoming-a, Hacking 2006, Lindberg \& Bagga-Gupta 2021). The study presented here aims to discuss and illustrate through examples from across time and geopolitical spaces how entities like language, identity and nation-spaces come into being and become.

The study takes cognizance of the monolingual and monocultural myths embedded in hegemonic stances that continue to keep the fires of the onenation-one-language ideology burning. It furthermore takes as points of departure the recent proliferation of concepts that theoretically challenge and make inroads against the monocentric biases that naturalize such myths. Illuminating human doings and paying attention to the multiplicity of "waysof-being-with-words" (Bagga-Gupta 2014), this study attempts to accomplish two issues. First, it tries to explicate what we call a "Second Wave of Southern Perspectives", SWaSP wherein the role of "doing language" or languaging is both a key dimension of the multi-scalar organization of life inside and outside institutional physical-digital spaces, and of the remembering and re-enforcement of boundaries as dimensions of belonging. Second, by juxtaposing ideas about belonging and (shifting) boundaries across timespaces, this study highlights the mechanisms involved in contemporary re-turnings to archaic conceptualizations of language, identity and nation-spaces across global settings. 
By engaging with historically produced and ongoing productions of spaces and named-groups through boundary-markings, we attempt to illustrate and thereby disturb the oppressive reductionism inherent in conceptualizations related to communication, culture, and diversity by juxtaposing four cases from across the global-North/South, including the South in the North and the North in the South. These include two regions in different continents and two large-scale human displacements at different points in time:

1. Sápmi across northern Scandinavia and Russia,

2. Nagalim in the tri-junction area of the eastern parts of India, Myanmar, and China,

3. massive displacements that ensued during the violent emergence of the nation-spaces of India and (West) Pakistan through the creation of the Radcliffe Line in 1947, and

4. the post-March 2020 urban to rural Pandemic induced exodus across the internal boundaries of the nation-spaces of India.

While contemporary globalization discussions in the media and the scholarship explicitly center-stage issues regarding language and essentialized communities on the one hand, and economy and migration on the other, bounded conceptualizations that are implicitly re-imposed are attended to in this study by making visible complexities that emerge by directing attention towards banal languaging across the cases. To this end we draw upon contemporary policy, scholarly and mass-media reports, and discussions to present these four cases.

In addition to our positionality of being scholars who are invested in the multidisciplinary areas of communication studies broadly, ${ }^{1}$ southern theory, sociocultural perspectives, the learning sciences, identity scholarship, and situated in nation-spaces generally understood as the global-North and global-South, we frame ourselves as "perpetual migrants" whose lived experiences are not inconsequential for the purposes of this study. In addition to our liminal migrancy across disciplinary boundaries, we are mobile across nation-spaces in our positions as scholars and humans born in specific localities and whose lives are anchored with kinship ties to other specific localities. Calling several geopolitical nation-spaces home is thus a normal dimension of our mobile existence. We live, work and have nurtured children in the nationspaces of 10 million-strong Sweden and 125 million-strong state of Maharashtra

1 This includes areas glossed as mono-multilingualism, literacy, multimodality across digitalanalogue spaces and the use of semiotic resources in meaning-making. 
in India ${ }^{2}$ respectively. We connect with family dispersed across the globe including, and of relevance to the cases we focus upon in this paper, those who call or called the regions of Sápmi, Nagalim, urban spaces in the Indian sub-continent and land that became (West) Pakistan, home. Furthermore, our scholarly work takes us across the planet, and we actively engage in academic discussions regarding the issues we engage with here. In addition to this perpetual mobility, we are languagers who language in named-languages in the oral/verbal, written and signed modalities. We live and work using semiotic resources from different named-languages, in addition to being invested in the communication and language studies scholarship specifically. Our positionalities - we argue - assists navigation across the liminal spaces that we focus upon in this study by enabling a heightened reflexive stance, and as we explicate in Section 2, this affords an important mobile gaze.

This multidisciplinary study takes an intersectional point of departure bringing together and contributing to southern theory, communication sciences, language studies and identity scholarship. Section 2 explicates tenets of our theoretical leanings before we, in Section 3, present the four cases that constitute the point of departure for locating our thematized and SWaSP theorized discussions in Section 4. This means that the first aim of explicating the nature of a SWaSP framing is dealt with in Section 2 and the second aim regarding the nature of archaic conceptualizations vis-à-vis language, identity and nation-spaces across time and space are focused upon in Sections 3 and 4.

\section{Spelling Out Some Premises}

Theory [...] need not be seen as an abstracted a priori point of departure, of which the given empirical findings are but an illustration or confirmation (or a negation, as the case may be), nor is it an equally abstracted domain that can be pointed to as the final result of prior processing of empirical data (HASTRUP \& WALTERS 2012:206).

We sidestep an explication of "a" theory and instead spell out premises that guide our explorations resulting in the three themes that emerge from the analysis of our four empirical cases. This does not imply that our work is without a theoretical foundation. On the contrary, a key premise that shapes this study is troubling the use of theories as straight-jackets where paying homage

2 India's population is reported as being 1.38 billion (India Population 2020), Worldometer - Real Time World Statistics, accessed 22 July 2020, https://www.worldometers.info/ world-population/india-population/). 
to specific boundary-marked traditions constitute points of departure. Instead, we spell out some premises that have a bearing on our present interests related to language, identity and nation-spaces and articulate these in terms of SWaSP.

We reckon that an (ongoing) first wave of southern thinking is marked by both challenges towards colonialism and awareness building of "anticolonial" and "postcolonial" stances inside and outside intellectual scholarship (see Fig. 8 presented in Annexure). Thus, the lives and writings of M. K. Gandhi and intellectual works by the trinity Said-Bhabha-Spivak can be seen as key in anticolonial and postcolonial areas. These overlap with a somewhat later recognition that a colonial stance is thriving in nation-spaces irrespective of their colonial heritage. This later "decolonial" scholarship emerges particularly from South American spaces from the 196os onwards. A SWaSP framing takes a point of departure in this ongoing non-linear trajectory of thinking and makes relevant the continuing colonial order of things as the natural order of things, particularly in mainstream academic scholarship. It encompasses and intersects with theoretical frameworks where issues of communication are central. Recognizing the important work in the first wave, SWaSP furthermore, attempts to illuminate the naturalizations of hegemonies in societal arenas at large, including the scholarship.

The premises that collate towards a SWaSP framing (Fig. 8 presented in Annexure) emerge from different named-theoretical positions (which are currently disassociated), that we conceptualize as two clusters (see also BaggaGupta forthcoming-a, Bagga-Gupta and Carneiro 2021, Bagga-Gupta and Messina Dahlberg 2021): sociocultural, dialogical and integrationist perspectives (Hutton Pablé \& Bade 2011, Linell 2009, Makoni 2011, Säljö 2010, Vygotsky 1934/1962, Wertsch 1998), and southern, anticolonial, postcolonial and decolonial framings (Comaroff \& Comaroff 2009, Maldonado-Torres 2011, Mignolo 2009, Pattathu \& Barnett-Naghshineh 2020, Savransky 2017). Together, these clusters contribute to an understanding of communication or languaging as fundamental dimensions of human existence. From meaning-making performative standpoints, languaging cannot be reduced to sign systems or fractured semiotics; neither can languaging be mechanically and/or programmatically decoded, named, and categorized without flattening or destroying its complexity.

Words and language are taken to constitute inseparable dimensions of the entanglement of signifying practices. An important SWaSP caveat is that this premise relates to the language that scholars use in their explorations, i.e., how scholars clothe a phenomenon has significance. Thus, mundane languaging as well as scholarly languaging constructs and provides meaning alignments. Premises regarding the nature of human identity, discussed in different 
disciplinary domains, have for quite some time drawn attention to the doing of identity, rather than essentialized characteristics that are focused upon in mainstream identity-sector scholarship (Bagga-Gupta 2017a, 2017b). Such performative stances are related to labelling practices. Naming people as something is, from such a framing, consequential (Bagga-Gupta forthcoming-a, 2018, Hacking 2006). Implications of such a perspective are substantial to how ideas regarding individual identity and the identifications of collectives, including nation-spaces become marked, challenged, re-created and re-enforced. This suggests that languaging is fundamental to how identities are storied, and also that a researcher's languaging is complicit in their construction of their study object - researchers and scholarship exist within language.

Another key premise that builds from the above is how difference between entities gets storied. Pandey (2011) describes difference as

manifold and fluid. [something that] cannot be thought or organized along a single (say, cultural or biological) axis. Distributed along multiple grids, it comes in innumerable forms, appearing differently in different places: malleable, evolving elements and tendencies that come into view and disappear, change, coalesce, and reappear, in other forms, amid other networks, in other contexts. Thus, the idea of difference signals fundamentally and importantly, a history and politics of becoming - not of the already normalized, stable and relatively immutable" (p. 1, emphasis in original). Difference thus relates to processes that are always dimensions of becoming, in contrast to that of being and named.

Such thinking calls for a methodological-analytical stance wherein a researcher's mobile gaze constitutes a key premise. Building a loitering gaze (Bagga-Gupta forthcoming-b) across disciplinary domains and empirical

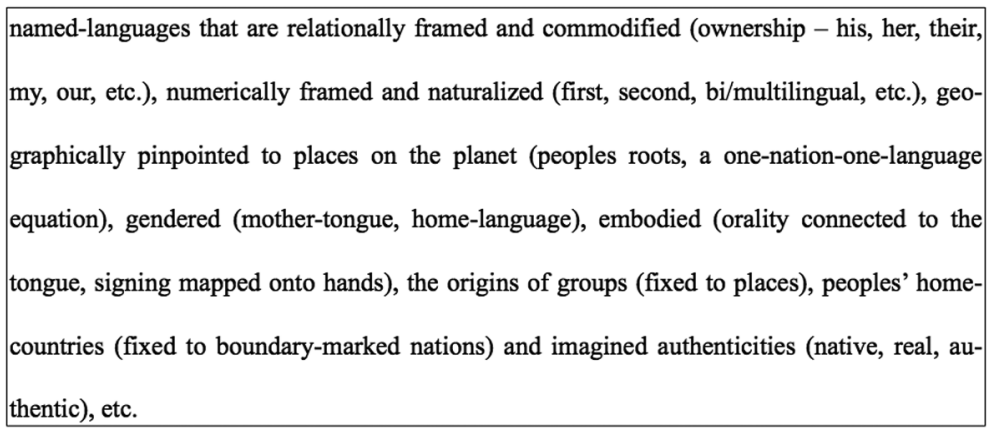

FIGURE 1 A non-exhaustive word-string on the work of words that mutually reinforce one another 
materials is thus fundamental to be able to leave aside programmatic methods and conceptual dogmas. Such "loitering mindwork" (ibid) cultivates sensitivity towards the work of words and metaphors regarding language, identity and nation-spaces that mutually reinforce one another. The non-exhaustive word string presented in Fig. 1 illustrates this entangled premise.

A researcher's loitering gaze thus can recognize that despite the increasingly established viewpoints (in the scholarship) accorded to the imagined nature of things like languages, the fluidity of human identities and the shifting boundaries that re-create nation-spaces, the words that researchers fall back upon (Fig. 1; see also Bagga-Gupta forthcoming-a, 2017a) when describing language, identity and nation-spaces are saturated with connotations that are bounded, essentialized and static. This premise draws attention to the need to disturb "received knowledge" and its source/s: from who, when and where specific types of knowledge originate, what is meant by it, which others are aligned to it, how its premises are articulated, what a specific perspective is labelled as, etc. These re-considerations and interrogations potentially enable de-naturalizing taken-for-granted understandings. We have previously discussed this type of conceptual mobility or a loitering gaze in terms of a "third position" or an "earthrise perspective" (see Bagga-Gupta 2018, 2017a, 2017b). SWaSP provides a multi-view perspective of intersectional entanglements of identity-positionings leading to multiple gazing positionalities in the scholarship. It enables critically gazing at dimensions of hegemonic "single grand stories" (Bagga-Gupta 2018).

Another premise, that feeds into a SWaSP framing, questions North-centric hegemonies in naming practices and knowledge constructions. Accentuating the need of loitering mindwork augmented with non-dogmatic (n)ethnographic strategies involves attending to ontologies, epistemologies, and methodologies reflexively, recognizing that words and discourses circulate across the globe, albeit often in a one-way directionality. Recognizing the existence of global-South spaces in the global-North and global-North spaces in the global-South constitutes a key premise that calls attention to spatial entanglements. It is not the replacement of current hegemonic vocabularies by Southcentric discourses or an additive stance that is called for. Rather, the task at hand relates to, interrogating what a Southern gaze can imply in a dialogically framed global/international scholarly task; we suggest that such a gaze calls for a Global-centric discourse that recognizes multiple frontline epistemological nodes (Bagga-Gupta \& Carneiro 2021). It is therefore pertinent to go beyond a universalist stance and instead draw upon a "turn-on-turn reflexivity" (Bagga-Gupta 2019) that has the potential to (i) make visible the naturalized boundaries and the gaze researchers (people and institutions) bring to 
different issues, and (ii) how such visibility can mobilize alternative ways-ofknowing. Highlighting alternative epistemologies at the margins necessitates going beyond understanding words as mirroring aspects of reality and instead calls for focusing on invisible, taken for granted norms.

Finally, empirically pushed scholarship that is collated with an engagement with mainstream scholarly domains is called for. A loitering gaze thus alters the premises of mainstream methodologies, the nature of data, including the units-of-analysis that scholars engage with. This premise has relevance for the four cases presented in Section 3.

\section{Framing Remembering Through Past and Contemporary Geopolitical Timespaces}

Our case-studies make visible salient hegemonic norms related to language, identity and nation-spaces that are naturalized in contemporary mainstream scholarly domains of the humanities, the educational sciences, and the social sciences. While the first two cases (3.1) defy demarcated territorial hegemonies, the next two (3.2) juxtapose two large-scale human displacements in the Indian sub-continent: the demographic dislocations and violence that emerged in 1947, and the post-March 2020 tragedies that emerged in the face of the urban to rural exodus in the aftermath of a strict pandemic lockdown.

\section{Non-bounded Geographies}

\section{Sápmi}

The term Sápmi refers to the land area across the nation-states of Finland, Norway, Sweden, and Russia (Fig. 2) whose national borders were created during the 18-19th centuries. Here live "the Sámi, a small and scattered people of ca 40-60 000, ...as both citizens and minorities” (Brantenberg 2014:37). The Sámi/ Saami are described as the first inhabitants of the Fennoscandia peninsula from 1000 years BC onwards (Historia 2019), and as "the most over-studied and under-understood people in Europe, if not in the world" (Anderson 1983:51). While the first "cross-border national Saami meeting was held in Trondheim" (Historia 2019) ${ }^{3}$ in 1917, conflicts with people positioned as non-Saami and the nation-state governments across which their territories exist, have continued

3 All original quotes in this paper have been translated by us; Swedish original "gränsöverskridande samiska landsmötet hålls i Trondheim". 


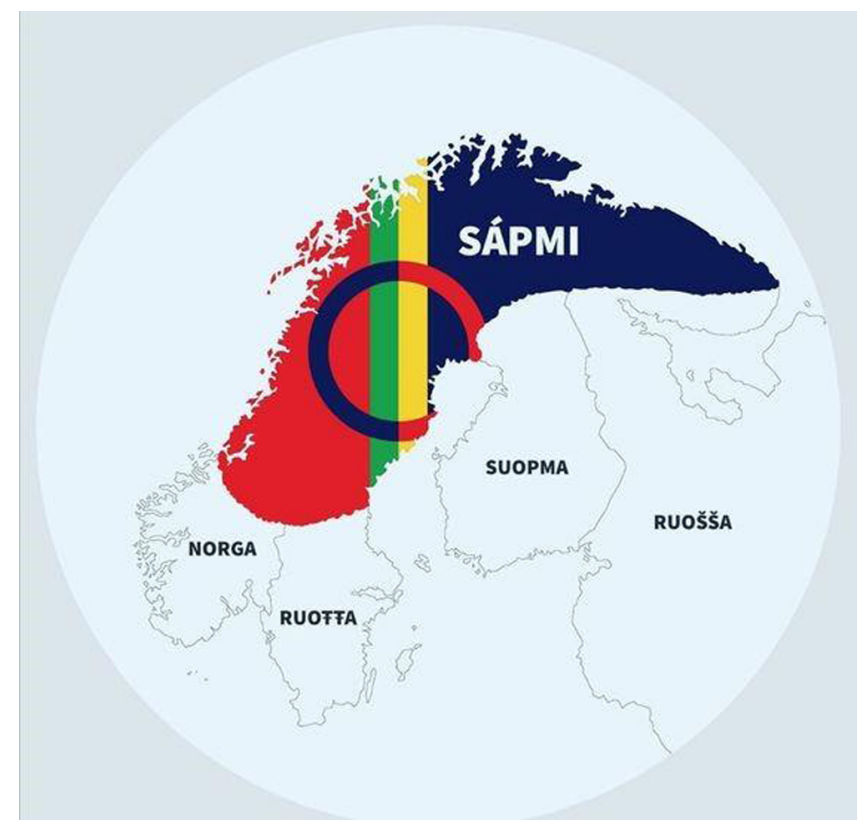

FIGURE 2 Representational figure - Sápmi, Saami land. (Source: Jukselapp on Instagram https://www.pinterest.com/pin/4471934380oo6o3651/)

ever since. While assimilation into the dominant nation-spaces slowed down, ceased, or reversed, conflict areas include the right to "remain Saami" in ways that Saami people deem relevant, the use of named-languages glossed as Samiska/Sami, and participation in matters related to natural resources (Beach 1992). Hate attacks towards the Saami increased in the aftermath of a 2020 landmark resolution regarding a long-standing dispute between the Swedish state and the Girja Saami district in Swedish nation-spaces which awarded the inhabitants exclusive rights to fishing and hunting on their lands (Maher 2020; see also Svensson 1976). Confrontations relate to the "encroachment of colonizers on a sparsely-populated region, followed by less direct exploitation by majority interests - dams and waterpower projects, mining, forestry, communications from roads to radio, all of which carve up the space and the articulation of niches grounding the livelihoods of the indigenous minority" (Anderson 1983:56).

The earlier labels "Lapp" and "Lappland" deployed by nation-states, nonSaami's and scholars when referring to Saami and Sápmi are experienced as derogatory and were dropped as part of larger social inclusion societal trends. The word Saami constitutes an umbrella term for "singular and plural, language and culture, individual and society, and noun and adjective" (Andersson 


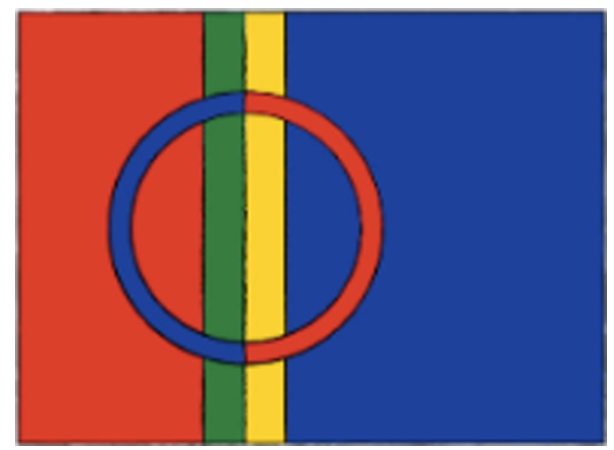

FIGURE 3 Saami flag representation

1983:57). While Swedish terms are currently used to index the people "Sami" and "Samer" and named-languages glossed as "Samiska", the Saami terms for the people, languages and towns and territories are different (Flaggan 2020). Fig. 2 presents nation-space names in Saami languages. These named-languages are recognized as belonging to the Finno-Ugric group, and the "dialects of Saami follow traditional watershed migration routes rather than national boundaries" (Andersson 1983:52).

Another signifying material dimension of meaning-making and identity is embodied in the Saami flag (Fig. 3). Adopted on 15 August 1986 and designed by Astrid Båhl from Skibotn, Norway, it was "approved by the Nordic Council of Ministers at a conference in Åre" in Sweden (Samer.se 2020). The flags four colors are taken from the Saami colt wherein green is seen as representing nature and land, blue stands for water, red for fire, warmth, and love, and yellow symbolizes the sun and a long life. The circles represent both the sun (red ring) and the moon (blue ring), symbolic of the Saami's close association with nature and their values. February 6 is marked as the "Sami National Day" in memory of the first national meeting in Trondheim (Beneath Northern Lights 2019).

\section{Nagalim}

Stretching across $1,20,000$ sq. $\mathrm{km}$ with a population of over 4.5 million (UNPO 2019), recognized by the UNPO, Unrepresented Nationals and Peoples Organization and represented in different global bodies (like the United Nations Human Rights Council, the United Nations Working Group on Indigenous Populations), our second case - Nagalim is a region that lies across South Asia 


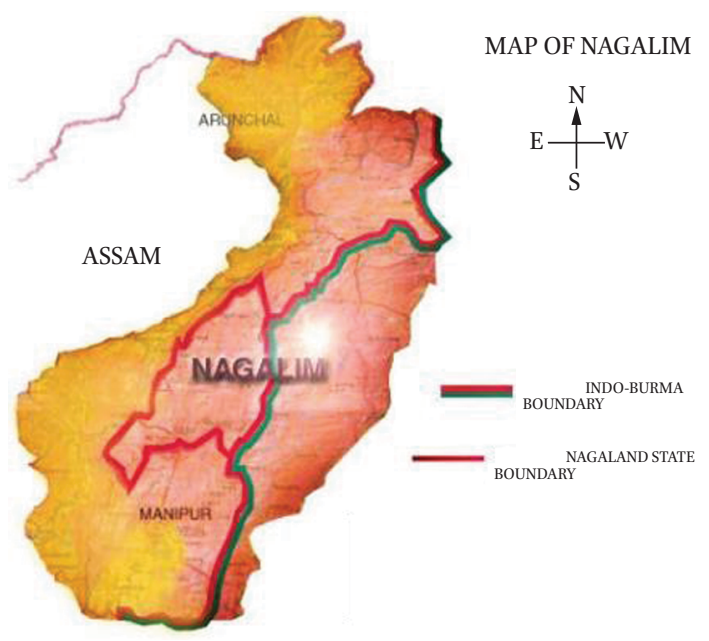

FIGURE 4 Nagalim representation (source: nagalim.n, accessed June 10, 2020)

and South East Asia. ${ }^{4}$ Lim is "Land/Nation" in Naga language. While "Naga" is seen as covering a diverse group of over thirty "ethnic tribes" inhabiting the states of Assam, Arunachal Pradesh, Nagaland, and Manipur in Northeast India, it also includes some Northwestern parts of Myanmar (marked as Burma in Fig. 4) and shares geo-strategic borders with China (Fig. 4).

While this region is politically contested (unlike contemporary Sápmi), each of its identified groups (like Sápmi) is recognized as having its own distinct language (marked as "dialect") and is governed by a Hoho council. A panNaga apex body, Naga Hoho was created in 1994 and its constitution, adopted in mid-March 1998, deals with culture, social practices, language/dialect, and issues of integrity of all Nagas (White Paper on Naga Integration 2002). While Pan-Naga Hoho has been described as "plurinationalism" that supports shared sovereignty, wherein control is distributed between central and regional authorities (Shimrah 2016:par.10), this idea of sovereignty is contested and continues to create conflict and resistance within the Indian Northeastern states, not least because of the geopolitical boundaries between nation-states. The Naga inhabited area in the Myanmar region of Sagaing also sees interventions by the Tatmadaw (Myanmar military) because of the presence of the National Socialist Council of Nagaland - Khaplang (NSCN-K) which controls an autonomous political unit in northern Sagaing.

4 The geographies of this region are marked by another set of boundaries and various dimensions of "naga". For instance, India is situated in South Asia and Myanmar in Southeast Asia. Discussing these boundary layers further is beyond our present scope. 
Racialization through labels like Chinki, ${ }^{5}$ Chinese and, since 2020, Corona, used by citizens across other parts of India builds on Northeasterners anatomical features, social practices, and political tensions with China. Reference to the "rest of India" as mainland India by some Northeasterners, further contributes to a center-periphery dialectic, enabling affinity with other neighboring nation-spaces. A further sense of alienation is fueled through the presence of paramilitary forces, with curtailments and regulations of civil and political rights in militarized zones through the enforcement of decrees like the Indian Disturbed Areas Act 1955, Armed Forces Special Powers Act 1958, and the Nagaland Security Regulation 1962 (Misra 2009, Moral 2018).

While calls for independence and continuing tensions can be noted through the 1980 formation of the National Socialist Council of Nagaland (NSCN) and a 2015 agreement between the Government of India and NSCN(IM), the very creation of the state of Nagaland in 1963 within the already independent nation-state of India failed to include all the Naga inhabited areas. The 2015 agreement provides mutual recognition and endorses "the unique history, the identity, the sovereignty, the territories of the Nagas [including their] legitimate right ...to the integration of all Naga territories" (UNPO 2019). While the Sápmi model based on the Saami autonomy pact is seen as a way to resolve such tensions (see anthropologist B. K. Roy Burman in Gangte n.d.), India's National Commission to Review the Working of the Constitution is wary of such efforts, least other groups follow suit (reported in Gangte n.d.).

The Nagalim flag (Fig. 5), hoisted for the first time on 22 March 1956, at Parashen in contemporary Nagaland when the Federal Government of Nagaland (FGN) was established, symbolizes - like the Saami flag - peoples attributes and their connection to nature. Its blue background is seen as symbolizing the sky and the three colors of the rainbow arch represent courage (red), beauty of the land and honesty of the people (yellow), and wealth and prosperity (green). The star represents Bethlehem and Christianity, the religion of a large Naga population.

Colonial vestiges, the materiality and language usage inherent in how communities and regions are established and remembered can be seen through the lens of these first two cases. While they point at the colonial and contemporary dimensions of two regions in what is often conceptualized as the global-North/South, the next two cases present snapshots of major displacements in the Indian sub-continent across time.

5 Chinki' is considered a racial slur and users of this term can be tried under the Indian Scheduled Castes and Scheduled Tribes (Prevention of Atrocities) Act. Under this Act, a person using the term can receive a non-bailable jail sentence of up to five years. 


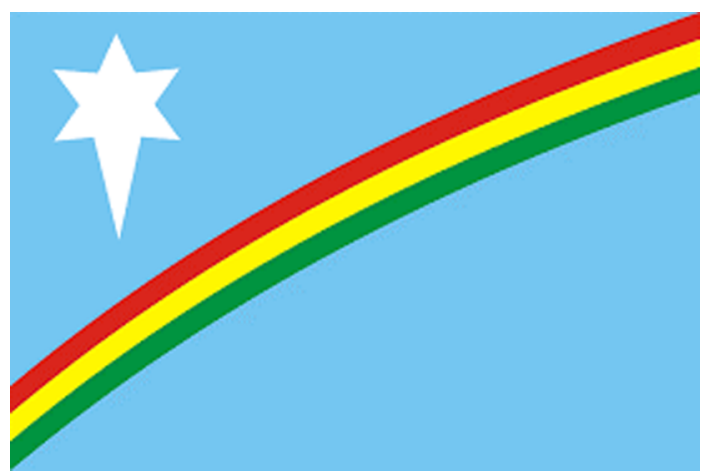

FIGURE 5 Representation of the Nagalim flag

\section{Boundary Framing and Exodus}

\section{Radcliffe Line}

Britain has been accused of being "astonishingly slow" (Chester 2009:25) but also irresponsible in establishing boundary lines at the end of its colonial era in the Indian sub-continent. While this end of empire constitutes "a vast and complex task, involving huge distances, many millions of people, all sorts of assumptions about census returns, as well as geopolitical, ecological, hydrographic, political and many other considerations", the handling of the task was given to "a lawyer, Cyril Radcliffe, who had little previous experience of India, certainly 'on the ground', and no experience of boundary formation" (MacKenzie 20og:ix, emphasis added). Radcliffe was given six weeks to create what became labelled "the Radcliffe Lines" 6 which created the nation-states of India and West and East Pakistan (Fig. 6) in 1947. The anticolonial leaders of the Indian sub-continent viewed Radcliffe's ignorance of the territories optimistically and as a sign of his impartiality. However, French (1997:321) positions the line-maker as the "ultimate Establishment figure" who was completely aligned with the empire's motives. Chester (2009) argues that while the creation of the line was minutely orchestrated and executed by the colonial rulers, a façade of responsibility was thrust on the anticolonial leaders.

The three primary stake-holders in the northwestern region - embodied in the political factions of Congress (Hindus and Sikhs) and the Muslim League

6 The Commission was tasked to create two lines - in the Northwestern and in the Northeastern part of the sub-continent. East Pakistan went on to, with the assistance of India, get its independence from West Pakistan and became Bangladesh in 1971. We focus here upon the Northwestern line.

7 These included key sites of worship and properties owned by the three groups. 


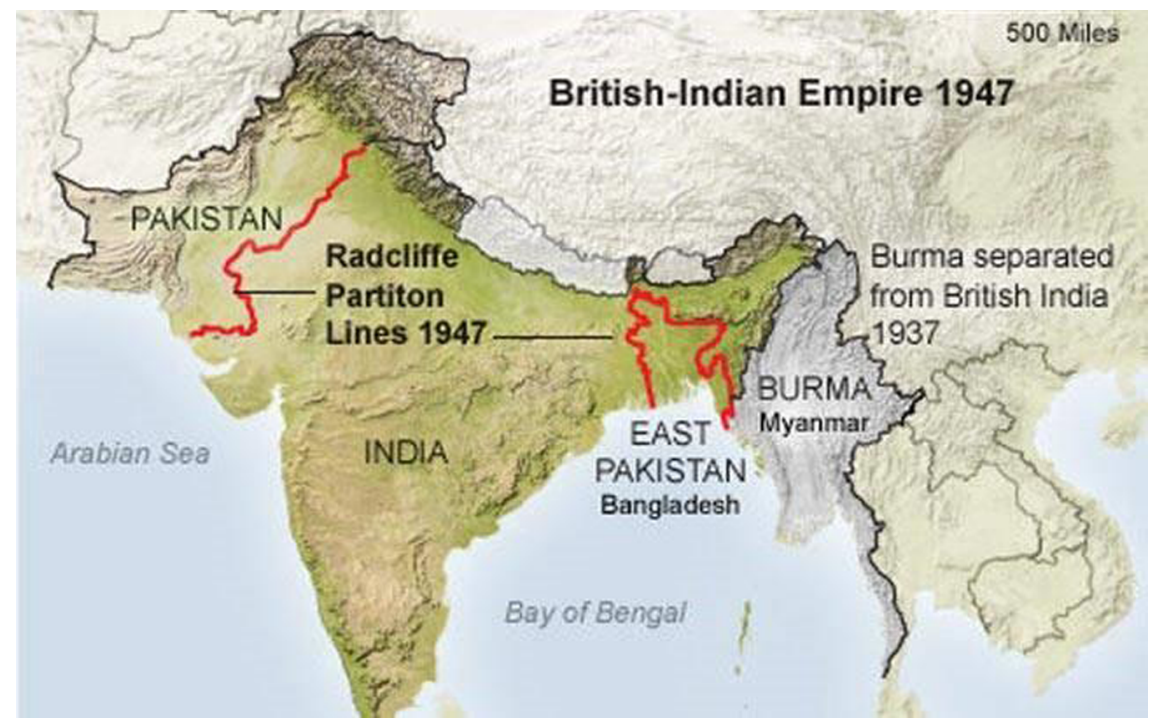

FIGURE 6 Representation of Indian sub-continent 1947 and the (red) "Radcliffe Lines" (source: India Today, 11 July 2020)

(Muslims) - submitted three maps to the commission with boundaries that made claims to "their territories". ${ }^{7}$ Given the colonial British government's "mandate to focus on religious demographics" (Chester 2009:79), the linecreator weighed in and prioritized "continuous majority areas" $(74,75)$ keeping the religious' groups in mind, rather than natural geographical borders created by rivers (this contrasts with the Sápmi case). The Sikhs were against being a minority within a Muslim state and many of their leaders were, like the Hindu Congress leaders, against the partition of India; they, together with Hindus and other religious denominations found themselves within the Indian nation. ${ }^{8}$ From SWaSP framings, line-making and boundaries here (including the cases of Sápmi and Nagalim) become dimensions of belonging and construct mechanisms that maintain archaic conceptualizations of language, identity and nation-spaces that continue to be re-enforced in contemporary times.

The Radcliffe Line would - all parties were aware - shape the lives of over 28 million displaced peoples of what is envisaged as "undivided British India" (Mosley 1962:198). What perhaps seems to have caught many, including Radcliffe, by surprise is the sheer scale of the ensuing exodus and massacres across the line, and its borderlands for months, years and the tensions it

8 While it is unclear why Sikh and Hindu demands were not attended to by Radcliffe, the close working relationships of the two groups within the Congress and proximities of Sikhism and Hinduism can perhaps explain why they were clumped as one monolith. 
successfully established well into the 21st century. The establishment of the formal Radcliffe commission,

found millions ...on the wrong side of the international border. From March 1947 onwards a steady movement of Hindus and Sikhs to safe havens ...had been taking place. The reason was that most violence and clashes took place in areas which now became part of West Pakistan where Hindus and Sikhs were in a minority. Nearly 500,000 of them had crossed the border before the Radcliffe [commission] was made public ...At the end of 1947, most of the 10 million unwanted Punjabis had been forced to flee their homes in the opposite direction to find refuge among their co-religionists. Some 500,000 to 800,000 Hindus, Muslims and Sikhs were killed ...It was the first grand-scale successful experiment after World War II in religious cleansing, which ...is a manifestation of ethnic cleansing (AHMED 2012, EMPHASIS ADDED).

While drawing attention to the sheer scale of the exodus, this discussion focuses on what is fixed and macabre through Ahmed's mobile gaze, a scholar from the Indian sub-continent who works in Sweden. Approaching the human need for continuity, the grand narratives based on established hegemonic continuities, are disrupted through his global-centric gazing.

Created as a symbol of freedom, the flag of the nation-state of India was adopted on 22 July 1947 (left, Fig. 7). It was raised at the stroke of midnight on 15 August 1947 at the लाल क़लि (transliterated to English in Latin:Lal/Red Qila/ Fort) in Delhi. Also known as the tricolor (flag), its colors are seen as symbolizing different virtues: saffron represents courage and sacrifice, white peace and truth, and green fertility, growth, and auspiciousness of the land. The अशोक छक्र (transliterated to English in Latin: Ashoka Chakra/Wheel) symbol in the center represents the wheel of the dharma law symbolizing truth and virtue that together constitute the guiding principles of the nation's people (Ministry of Home Affairs, Government of India 2002). The flag of the nation-state of
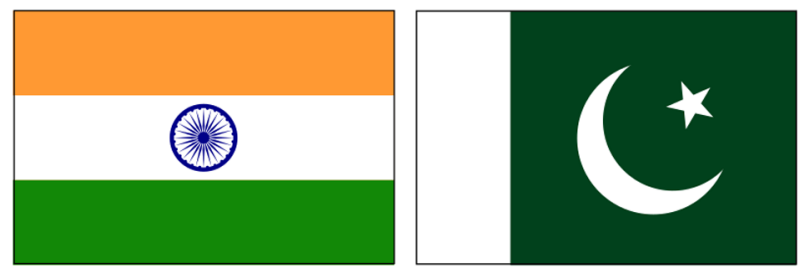

FIGURE 7 Nation-state flags that emerged through the Radcliff Line - India (left) and (West and East) Pakistan (right) 
Pakistan (right, Fig. 7) was adopted on 11 August 1947, three days before its independence. The dark green is seen as representing the majority Muslim population and the white, the remaining religious minorities, symbolic of a commitment to Islam and the rights of religious minorities. The crescent represents progress and the star light and knowledge (Ministry of Information and Broadcasting, Government of Pakistan 2009).

\section{0 (Post March/April): Urban Exodus}

Irrespective of why boundary lines are created, mobility has constituted the human condition across time. While different regions (in what is seen as the global-North), and urban centers (in all nation-states) have, since the industrial revolution, functioned as magnets for across and within nation-state migrations, the 2020 Pandemic witnessed - for the first time in history - a reversal of this human flow (Steinkopf-Frank 2020). Furthermore, urban centers, as our final case illustrates, constitute liminal spaces where humans are in perpetual transition.

The large-scale urban exodus within the nation-state of India, following one of the strictest lockdowns worldwide imposed in March 2020, highlights issues regarding how contemporary centers-peripheries are co-situated and co-dependent. The Pandemic induced "reverse migration" is seen as the result of a major "trauma" that includes "poor [urban] living conditions, overnight loss of livelihood, no social security" (economist Mehrotra in Nair 2020). Describing it as a "Biblical scale suffering" in a blogpost titled "The Lock Down Diaries (VIII)" (avayshukla.blogspot.com, accessed 21 May 2020), an author positions himself as a non-migrant middle-class citizen and his text as being about himself and

the burden ...of shame, that has been sitting on my back for the last few weeks [...I hang my] head in shame in the India of 2020. At belonging to a country and a society which exiles tens of millions from their cities, fearful of catching an infection from them, from a virus brought here, not by them, but by my brethren flying in from abroad ...Cocooned safely in our gated societies and sectors, we have locked out our maids, drivers, newspaper man, delivery boy and a dozen others who have built for us the comfortable lives we now desperately try to cordon off from the less fortunate. We have deprived them of their livelihoods ...I am ashamed that people like me can encourage the police to beat up the returning hordes for violating the lockdown, which, in the ultimate analysis was meant to protect "us" from "them" ...All age-old prejudices, bigotry, racism and 
narrow mindedness have reemerged ...They will reach their homes ultimately, those marching millions, minus a few thousand who will die on the way. They will not even be mentioned in the statistics: there will be no Schindler's list for them.

They were forced from their urban homes for the rural sites that they had left, sometimes decades ago, because these citizens had overnight lost their livelihoods and were doomed in the urban spaces of which they were an essential, but marginalized, part. This exodus became aptly labelled the unfolding of a "humanitarian crisis" where millions walked and, a few who possessed cycles, cycled across the length and breadth of the nation-sate. ${ }^{9}$ Similar to our 1947 case, this exodus too saw entire families with small children and the elderly trekking with their meager belongings. While the plight of the millions who were forced to flee in 1947 was not visible digitally, the scale of the 2020 exodus received visibility that was met with political silence for weeks, and no direct relief.

The overnight media visibility of the 2020 exodus exposed the very existence of the urban marginalized, including the perpetual nature of their migrancy and displacements. This contrasts strikingly with these peoples' envisioning's of urban centers as "their" homes. Revealing the prevalent social and economic disparities of large sections of urban spaces, these millions lack identity and residential proof and exist outside urban development envisioning's of community planning; they consequently find no place in urban social security schemes (Sahas 2020). 42 percent of these urban citizens do not have ration cards and 33 percent found themselves stranded in their own homes without access to food, water, or money (ibid). Perpetually positioned by others as migrants in liminal spaces of belonging, their crisis became exacerbated by Article 217 of the Indian constitution which places "inter-state migration" in the hands of the central government and not that of the state governments.

Talking with the four case-studies opens for illuminating the entangled entities that are labelled language, identity, and nations across timespaces. We deal with this in our final section by focusing upon the role of boundaries in relation to the ontologies of being and belongings vis-à-vis spaces and others. The discussion points to the sociomateriality of identity-positionings and

9 Swedish citizens who found themselves stranded in different parts of India on this sudden lockdown, and whose visas were not extended or who had no means to sustain themselves, received support from the Swedish Embassy (for instance, police certificates that enabled passage by private or Embassy organized transport across state boundaries to reach evacuation flights to Europe). This stands in sharp contrast to the situation of Indian citizens in their own land. 
the complicity of languaging in the creation of bounded language, identity, and nation-spaces, including what boundaries have meant and mean for the human condition.

\section{Discussion: On the nature of things, beings and becomings}

Ask anyone to imagine a world map, and the first thing that they will think of is the outlines of various modern nation-states ...Far from being an innate feature of our planet's landscape, or even having significant historical basis, most of the world's international borders were only created in the 2oth century, and they came into existence with only the stroke of a pen (THE DECOLONIAL ATLAS 2018).

Using a methodological-analytical SWaSP stance that draws on the scholar's mobile gaze, we explicate three overlapping themes that arise through the examination of how difference between entities gets storied. It is in this sense that the continuing colonial order of things, as the natural order of things becomes salient.

\subsection{Semiospheres: Connections, Boundaries, and the Materiality of Identities}

Nationhood status, in the context of people labelled as indigenous, can lead to "political realities and subversive political imaginaries" wherein part of people's "concrete realities [...is] to live and think about their rights and interests" (Biolsi 2005:240, 254). Lines and liminalities can here become markers of identities that are closely associated with symbols and emotions that sacralize territories based on what gets glossed as ethnic (Anderson 1996). Ethnicity related to racial and linguistic traits, as in the Sápmi and Nagalim cases, and religion as in the Radcliffe Line case, engages with nationalist and colonial grand narratives that claim independent, bounded territories based on collective memory and migration (Mukherjee 2017, Rudolph 2006). The Radcliffe Line explicates the legitimacy of belongingness with "only the stroke of a pen". Such line drawing is languaging (see theme 2) both in a metaphorical and factual sense and has repercussions for people's lives across all our cases.

Conceptualizations of spaces, that lines demarcate in tangible maps and the symbolic materiality imbedded in flags (and other artefacts), can be seen in terms of Lotman's (1984:208) continuum of semiotic systems that create semiospheres, i.e., a "semiotic space, outside which semiosis cannot exist". Territorial maps, in contexts that are contested (Nagalim) or imposed (Radcliffe Line) and are fixed (Sápmi) historically, function as organized spatial spheres which 
encompass ideas and semiotic models. The 2020 exodus case and its contestations in liminal spaces between state borders also attests to the tangibility of boundaries. A semiosphere - irrespective of whether it is nation-states, within nation-states or transnational regions - is surrounded by a boundary whose internal constituents are both heterogeneous and homogeneous. They are storied into being through symbolic means (see theme 2). Such boundaries, as Lotman suggests, can separate:

settled people from the nomadic ones, the town from the plains; it may be a state frontier, or a social, national [...or] any other kind of frontier ...In fact, the entire space of the semiosphere is transected by boundaries of different levels ...These sectional boundaries ...create a multi-level system $(1990: 131,138)$.

Semiospheres, relevant for all our four cases, connect to boundaries that are consequential for peoples' lives: being subjected to racialized treatment and suffering at best, and death at worst. Lines materialize geographical spaces that get mapped for securing and restricting identities. Lines create intersecting spaces of explicated and contested identity formations that then have consequences for human lives - both in historical and contemporary times. It is an ad hoc deployment of lines and curtailments that continues to enable forced human mobilizations of millions of people boxed in as belonging to specific imagined communities: while a 1947 colonial decision, built on pre-determined group identities connected to land, saw millions on the "wrong" side of a line migrate and hundreds of thousands massacred, a 2020 urban exodus, precipitated through silent marginalization's, witnessed millions march, suffer and perish. Our mobile gaze across the cases highlights that urban melting pots, built in large measure upon the labor of its daily wage earners, constitute imagined and tangible liminal spaces. The Pandemic gave rise to the imagery of rural migrants, who ironically were not always welcomed back to their onceupon-a-time village-homes when they reached them in 2020. Their material existence in the urban shadows suddenly became visible at a historical moment when they could no longer sustain themselves in their urban homes.

A semiosphere's creation is contingent upon multiple environments that collate through languaging to negotiate new types of information (Lotman 1984; see also below). Scholarship is complicit in this collation process. Hutton's (1999) in-depth exploration of primary sources in relation to Nazi Germany convincingly describes how linguistics uses a "quasi-natural' dimension [...that connects] people to territory; dialectology maps the variation of language in contact with the landscape, which is viewed as the natural linguistic order of things" (1999:297, emphasis added). Similarly, the map semiosphere builds on 
spaces that become icons and are naturalized in terms of the "linguistic order of things". Furthermore, semiospheres are the result of and the condition for the development of culture and across time their multi-levelness constitute collective memories of positionings, beings and belongings (Lotman 1990).

Similarly, the sociomateriality of flags - embedded in design, colorscape and meanings inscribed through semiotic resources - constitutes an agency of things conveying ideological evolutions and cultural symbolism that unify nation-spaces - newly formed (like India and Pakistan) or in the liminality of becoming (like Sápmi and Nagalim). The non-existing flags of the urban othered, both testify to their invisibility and thereby precarity, and being without contemporary or historically fixed territory or territories-in-the-making in urban and rural settings; thus, dooming them to fuzzy invisibility and real precarity. The officially recognition accorded to the Sápmi flag, sees it being hoisted annually across nation-spaces on 6 February, the "Sápmi National Day". Such markings connect a people with a territory, albeit one that overlaps with sociomaterial symbols and territories of other peoples. Overseeing business related to the Sápmi territory, the Saami parliamentary council determines its "national" symbols. In comparison to the Sápmi and Nagalim flags, the mid-1947 creation of flags of India and Pakistan are based on the symbolic markings of two political parties - the Indian National Congress and the Muslim League - prominent during anticolonial freedom struggles. Flags constitute, in this sense, mnémotechniques of identity, belongingness and nationalism that are strong sources of cultural memories, historicized through the negotiation of power structures and resistance. Through the multilayered interplay of signage, they communicate values which are held sacrosanct. For instance, marking aspirations and a strife for self-determination, Nagalim and Sápmi narratives are driven by ethno-nationalism, resembling narratives of newly born and existent nation-states. Nationalism, as Hutton (1999) aptly illustrates, is associated with a community's imagination of shared roots, history, and the pursuit of governance of specific territories and people's, working as a strong undercurrent for equity of those who "belong" and those who do not. Applying an analytical mobile gaze at the semiospheres of sociomaterial things, thus displays multiple semiotic levels that constitute engaging and activating spaces of identity constructions.

\section{Languaging and Remembering}

A second theme that emerges through the juxtaposing of our cases resonates with memories of belonging and the complicit role of languaging introduced 
above. Historically produced and ongoing productions of spaces and peoples through migrations - dramatically illustrated through the 1947 Radcliffe Line and the non-permeable state boundaries that became tangible in $2020-$ collate to form criteria of belonging and membership of named-communities at local, regional, state and national-levels. These productions of spaces and peoples also display liminality, both in the territorial claims of the Saami and Naga people, and the urban othered migrant status of people living for decades and generations in cities. Remembering and historicizing gets accomplished through stories signified in maps or flags of both nation-states and nations-spaces-in-the-making.

Furthermore, named-languages are conceptualized as being contained within and belonging to named-nations, states, and peoples within nationspaces and these in turn are complicit in the constitution of internal, transnational, and global flows; migrations in this manner continue to be experienced as deviant patterns without an easy fit within the monocentric monolingual (nation-state) imagination. Here languaging the other can be illustrated in the colonially framed identity traces existent in the use of slurs: calling out Indian citizens in Indian spaces to "go to Pakistan" or "Pakistani"10 in the 21st century builds upon real or perceived religious alignments or differences. Re-constituting colonial vestiges of division, recipients of such labels become encapsulated in contemporary liminal spaces. The 2020 reverse-migration, policed at boundaries inside the nation-state of India, also exemplifies such liminal spaces, wherein othering occurs through semiotic categorizations that transform settled urban people into rural migrants, thus racializing them as outsiders who do not belong and thus, are unworthy of support. The marching millions are expected to return to imagined rural homes, in ways that echo how settled people become perpetual "European others" in European spaces (Pattathu and Barnett-Naghshineh 2020).

Languaging constitutes an inseparable dimension of entangled signifying practices; it presupposes and co-creates human ways-of-being and identitypositionings. Framed as belonging to the "informal or unorganized" sector, many blue-collar migrant workers are seen as belonging to the Dalit community, ${ }^{11}$ irrespective of their alignment to the caste system. This may be related to the etymology of the word Dalit, which in Sanskrit means "broken or scattered".

10 Such slurs are equivalent to the use of the term "Paki" in Anglo-Saxon spaces of contemporary Britain.

11 The word Dalit was repurposed as a dimension of 19th century reforms to mark a distance from the lowest caste Shudras, who were also called the "untouchables" (OED Online. Oxford University Press, June 2016). 
Marked as "untouchables", ${ }^{12}$ Dalits are required to be kept at a distance. Did the 2020 Pandemic inadvertently reinforce this idea of "social distancing" between the urban rich and those associated with " $3 \mathrm{D}$ work"? 13

Discussions regarding indigenous communities' rights over "their" historicized "traditional lands" or "homelands", including "their" rights to use "their" lands and resources for "their" economy and livelihood and "their" rights to "their" named-languages are looped (Hacking 2006) in banal languaging and terminological meshwork's of ownership of natural resources - both intellectual (language) and territorial (land); these become naturalized ways-of-being-with-words. A "native land" and a "native language" are constructed as dimensions of memories and imagined essentialized identities through the entanglements of folklore, semiotic resources, and social practices - for both minoritized and majoritized groups. The Saami's nomadic lifestyles associated with reindeer herding, gets them tagged historically as "homeless" by people who do not self-identify as belonging to Sápmi (Brännlund 2019). Such framings and positionings are common to many liminal narratives. The racial attacks that the Saami face in the aftermath of recent legal decisions can be linked to the history of the Swedish State Institute of Racial Biology established at Uppsala University in 1922 whereby the Saami were particularly scrutinized (Ericsson 2020). In this regard it is both important and interesting to note that the government banned the use of the term "ras" (English: race) in 2008 arguing that the term did not apply in Sweden. ${ }^{14}$

A chronology tracing the establishment of accords, acts, legal dispute outcomes - legal decisions about place names, group designations, responsibility and counter-responsibility framings, rights, etc. - are also storied through social engineering. This plays a role in how territories and boundaries get controlled. Nagalim's ethno-political claim, for instance, builds on the fact that established state-political boundaries are not in sync with indigenous communities' own perceptions of their named-ethnicities. Nomenclature that marks an area as "disturbed" because of a "break down of law and order", associated with Nagalim and the existing Indian state of Nagaland, normalizes hegemonic control and the naturalization of force, which gets termed "crackdown". Here Kaldor's (2013) "New Wars" thesis is applicable, in that it highlights the interplay

12 The Indian constitution banned, in 1950, the practice of untouchability based on caste.

13 I.e., work that is marked as being Dirty, Dangerous and Demeaning (Bhagat, Sahoo, Roy \& Govil 202O). 3D emerges from Japanese terms that refer to Dirty, Dangerous and Demanding (Connell 1993); the term "3D work" has become popular particularly with regards to the labor of migrant workers.

The term re-entered Swedish discourses around 2019. 
of identity politics, human rights violations, a strong presence of the paramilitary within the social context of corruption and inefficient administration that colors conflicts in transnational contexts. McGarry's (1998) demographic engineering also illuminates some of these boundary framings given the presence of colonial and/or state-directed movements of ethnified and racialized groups as a technique of conflict regulation. We also see this in both the documented mass migrations and violence from the 1947 and 2020 exodus cases.

The banal languaging and vocabularies we live by when attending to such issues in the scholarship, often make use of quotation marks in attempts to mark a distanced voice: for instance, in a phrase like "civilizing" the "natives" or "tribals". However, assumptions embedded in cultural imperialist projects get re-produced, nevertheless. The ideological contestation of languaging thereby constitutes ripple effects that communicate boundary framings and positionalities, determining containments and assertions of nationalities, race, and ethnicities; this is apparent in the gatekeeping role of languaging and sociomateriality,

\section{Gatekeeping, Liminality and Belonging}

The idea that nations and communities are imagined through modern maps that create a national consciousness is not new. Disputes in the context of Nagalim illustrate this through clashes of imagined lines and differences in the interpretation of the Naga-Lim i.e., Naga-Land/Nation. Here human-made territorial definitions re-create a nation's geo-body which deploys "classification, communication, and enforcement on people, things, and relationships" (Winichakul 1994:16-17). The geo-body describes the operations of the medium of territoriality in specific social contexts which then feeds into a nationhood idea. This also points to the strategic Indo-Myanmar-China frontier policies where the Naga communities are scattered, further contributing to identity constructs and mobilisations. Winichakul argues that before the arrival of the British colonizers, the existence of overlapping or multiple sovereignties parallel with lands where no sovereignty was claimed, was not unusual (this is akin with the situation of contemporary Sápmi).

Bounded map constructs travelled with colonizers who used them to administer (for their own gains) and control the peoples of the Indian sub-continent. This included building diplomatic ties with sovereigns whose territories they annexed across the 18th and 19th centuries. For present purposes, the important point is that not only did such processes create the historicized demarcations in Nagalim spaces, but spilled over into contemporary times, leading to 
further disagreements with more recent boundaries, including people's understandings of territory and sovereignty that in turn feeds the flames of armed resistance. In this sense, territories are replaced by mapped geo-bodies resulting in the emergence of nation-spaces. Hence, mapped geo-bodies become models for, and not models of, what they purport to represent (Winichakul 1994). Such concrete snapshots point to the continuing workings of the empire.

The Sápmi case also offers insights in relation to liminality and belonging. Discussing extrinsic and intrinsic factors that shape reindeer management, Anderson (1983), Beach (1981) among others, highlight how Saami relocations clash with the influx of colonists creating competition for land. The "Swedish government, in a gatekeeping process, not only dictates which Saami may carry out reindeer herding and husbandry, but even the type of reindeer management" that was possible (Anderson 1983:54). Thus, a priori collective social identities vis-à-vis current nationalist discourses within and across boundaries constitute outcomes of power structures and struggles within conceptualisations of liminality.

The gatekeeping creation of an "inner line" by the British colonizers of the Indian sub-continent in 1873 also illustrates this issue. A colonial construct for political and administrative convenience and presented as a form of protection for indigenous communities, this line included the Naga areas. Given that such inner lines were not "natural" (Robb 1997), the very naturalization of such imaginary across time has enabled other states in contemporary Northeastern India to demand "inner line permits". Similarly, the Radcliffe Line drawing illustrates both the creation of two nation-spaces in 1947, their re-birth (East Pakistan becomes Bangladesh) and re-enforcements (continuing contemporary tensions between nations). While scholars who focus on borders and studies of South Asia attest to the fact that Radcliffe had deficient and incorrectly scaled maps to help him in this task, a SWaSP mobile gaze enables drawing attention to the very task of drawing lines to organize human difference of specific kinds; it is the empirical circumstances that lead to line-making that needs scrutiny. Chester (2009:78), for instance, argues that, while Radcliffe, whenever possible tried to build upon the existing British administrative borders, such:

use of administrative boundaries reinforced the impact of imperial rule. The territory of the raj was honeycombed with boundaries of all kinds, which had been maintained partly as a means of perpetuating British imperial control, although many had Mughal origins. Radcliffe's award retained for the postcolonial states of India and Pakistan (whether they wanted it or not) a central element of the legacy of imperial rule: the raj's political boundaries marked the (ostensible) stability of its rule. 
As such the empire never ended and Britain secured a grip on India and Pakistan even after 1947 (https://decolonialatlas.wordpress.com/2015/04/24/ south-asia-without-borders/). Specific historically flavored ideologically framed boundary metaphors, related to language, identity, and nation-spaces, wherein "the weight of two centuries of nation-state thinking" (Blommaert 2015:1) continues to hound us in the 21st century. Gatekeeping of the central idea of belonging through markers connected to land in this manner continue to create a colonial order of things.

To conclude, bringing a SWaSP mobile gaze discussed within three overlapping themes highlights the dialectic ways in which individuals and communities on the one hand and semiotic resources on the other, in contested and/or permeable spaces, are entangled. Expressions of lived histories, liminality and lim collate as semiotics of identity representations. "The fault lines between civilizations will be the battle lines of the future" (Huntington 1993:22). As our cases highlight, a fault line war continues to be fought, one that involves symbols of cultural and/or ethnified identity. The gatekeeping hegemonic praxis of drawing lines relates to insular geopolitics which overrides geopolitical realities. These endogenous and exogenous mechanisms then give rise to what is glossed as mixed identities in the liminal border spaces which create appropriations of cultural, political, and territorial realities. Engaging with four snapshots of geopolitical timespaces and concepts like liminality, borders/ boundaries, and memory, against the backdrop of anticolonial, colonial and post/decolonial gatekeeping political mechanisms, we have illuminated myths and imaginations that give credibility to the idea of bounded language, identity, and nation-states, including the role of languaging as constitutive of these processes.

SWaSP tenets and in particular a SWaSP mobile gaze, we argue, both opens and aspires to re-think the cultivation of epistemologies and understandings that are invisibalized but nevertheless work as strong pointers and metaphors that mutually re-enforce one another: peoples roots and home-spaces, the origins and territories of groups, the concept of imagined entities, ownership of named-languages, etc. These understandings are disturbed, shaken, re-positioned by human mobilities (including researchers mobilities and our mobile gaze) across timespaces. SWaSP tenets raise issues regarding the cost of disruptions, the counter-flows related to colonially marked mobilities and pandemic induced reverse-migrations. Juxtaposing contemporary and historical cases regarding the co-creation of identity tensions of individuals/communities, we argue that multisided processes contribute to a re-turning to and the naturalizing of archaic conceptualizations pertaining not only to language, identity, nation-spaces, but also nationalism. 


\section{References}

Ahmed. "1947 Pre-partition India: Radcliffe Award \& Punjab." English - Europe Solidaire Sans Frontières (blog). 2012. URL: https://www.europe-solidaire.org/spip. php?article26113 Accessed 16 July. 2020.

Anderson, Benedict. Imagined Communities: Reflections on the Origin and Spread of Nationalism. London, Verso, 1983.

Anderson Malcolm. Territory and state formation in the Modern World. Polity Press, Cambridge, 1996.

Al Jazeera. "Modi Seeks 'forgiveness' from India's Poor over CoviD-19 Lockdown." Al Jazeera. Last modified March 29, 2020.

Bagga-Gupta, Sangeeta. Languaging: Ways-of-being-with-words across Disciplinary Boundaries and Empirical Sites. In H. Paulasto, H. Riionheimo, L. Meriläinen \& M. Kok (Eds.) Language Contacts at the Crossroads of Disciplines (89-130). Newcastleupon-Tyne: Cambridge Scholars Publishing, 2014.

Bagga-Gupta, Sangeeta. Languaging and Isms of reinforced boundaries across settings: Multidisciplinary Ethnographical Explorations. In D. J. Rivers \& K. Zotzmann (Eds.) Volume 11 Series Language and Social Life. -isms of Oppression in Language Education. (203-229). Berlin: Mouton de Gruyter, 2017 a.

Bagga-Gupta, Sangeeta. Center-staging language and identity research from earthrise perspectives. Contextualizing performances in open spaces. In S. Bagga-Gupta, A. L. Hansen \& J. Feilberg (Eds.) Identity revisited and reimagined. Empirical and theoretical contributions on embodied communication across time and space. (65100). Rotterdam: Springer, $2017 \mathrm{~b}$.

Bagga-Gupta, Sangeeta. Going beyond "single grand stories" in the Language and Educational Sciences. A turn towards alternatives. Special issue: "Language Across Disciplines". Aligarh Journal of Linguistics. 8, (2018), 127-147.

Bagga-Gupta, Sangeeta. Learning Languaging matters. Contributions to a turn-on-turn reflexivity. In Bagga-Gupta, Sangeeta, Anne Golden, Lars Holm, Helle P. Laursen, and Anne Pitkänen-Huhta (Eds.). Reconceptualizing Connections between Language, Literacy and Learning. (103-125). Rotterdam: Springer, 2019.

Bagga-Gupta, Sangeeta, and Aprameya Rao. "Languaging in digital global SouthNorth spaces in the twenty-first century: media, language and identity in political discourse." Bandung:Journal of the Global South 5, no. 1 (2018), 1-34.

Bagga-Gupta, Sangeeta, and Alan Carneiro. Commentary: Nodal frontlines and multisidedness. Contemporary multilingual scholarship and beyond. Special issue: Advances in the studies of semiotic repertoires. International Journal of Multilingualism.18(2), 2021. https://doi.org/10.1080/14790718.2021.187670o.

Bagga-Gupta, Sangeeta, and Giulia Messina Dahlberg. On studying peoples' participation across contemporary timespaces: Disentangling analytical 
engagement. Outlines. Critical Practice Studies. Special Issue: Transmethodology: Research Beyond Proceduralism. 22(1), 49-88, 2021. https:/tidsskrift.dk/outlines/ article/view/125861.

Bagga-Gupta, Sangeeta. RE. Vocabularies we live by in the Language and Educational Sciences. In Severo, C, Makoni, S, Abdelhay, A, \& Kaiper, A. (Eds.). Language and Higher Education in the Global South: Emerging technological, ideological and theoretical approaches. New York: Routledge forthcoming-a, 2022.

Bagga-Gupta, Sangeeta. Circulating discourses in the places and spaces of planet earth. On loitering and a mobile gaze in the Language Sciences. In Deumert, A. \& Makoni, S. (Eds.). From Southern Theory to Decolonizing Sociolinguistics - Voices, Questions and Alternatives. Cleveland: Multilingual Matters. forthcoming-b, 2022.

Beach, Hugh. Reviewed work: "Herds of the Tundra: A Portrait of Saami Reindeer Pastoralism." By Robert Paine. Anthropologica, vol. 36, no. 2, 232-234, 1992.

Blommaert, Jan. "Commentary: Superdiversity old and new." Language \& Communication 44 (2015), 82-88.

Beneath Northern Lights. "The Sami Flag- "Sami are the children of the sun" Beneath Northern Lights." Beneath Northern Lights. January 29, 2019. URL: https:// beneathnorthernlights.com/the-sami-flag/.

Bhagat, R. B., Reshmi R.S, Harihar Sahoo, Archana K. Roy, and Dipti Govil. The COVID19, Migration and Livelihood in India. Mumbai: International Institute for Population Sciences, 2020.

Biolsi, Thomas. "Imagined geographies: Sovereignty, indigenous space, and American Indian struggle." American Ethnologist 32, no. 2, 239-259. doi:10.1525/ ae.2005.32.2.239, 2005 .

Brännlund, Isabelle. "Familiar Places: A History of Place Attachment in a South Sami Community." Genealogy 3, no. 4, 54. doi:10.339o/genealogy3040054, 2019.

Brantenberg, Terje. (2014). Politics of Belonging - The Sámi Movement. In Marit Anne Hauan (Ed.), Sámi Stories: Art and Identity of an Arctic People (37-56). Tromsø: Orkana Akademisk.

Chester, Lucy. Borders and conflict in South Asia: The Radcliffe Boundary Commission and the partition of Punjab. Manchester: Manchester University Press, 2009.

Chester, Lucy P. Borders and Conflict in South Asia: The Radcliffe Boundary Commission and the Partition of Punjab. Studies in Imperialism. Manchester: Manchester University Press. 2013.

Comaroff, John L., and Jean Comaroff. Ethnicity, Inc. Chicago: University of Chicago Press, 2009.

Connell, John. Kitanai, Kitsui and Kiken: The Rise of Labour Migration to Japan. Sydney, Australia: Economic \& Regional Restructuring Research Unit, University of Sydney. 1993. 
Ericsson, Martin. "What happened to 'race' in race biology? The Swedish State Institute for Race Biology, 1936-196o." Scandinavian Journal of History, 1-24, 2020.

"Flaggan," Internet Website: Samer.se, Accessed July 4, 2020, URL: https://www.samer. se/1146.

French, Patrick. Liberty or Death: India's Journey to Independence and Division. London: HarperCollins. 1997.

Gangte, Gin. "Degree of Self Governance III." Accessed July 11, 2020. URL: https://e-pao.net/epSubPageExtractor.asp?src=news_section.opinions.Degree_ of_Self_Govenance_III.

Hastrup, Frida, and Bradley B. Walters. "Theory and methodology in causal research: a commentary." Geografisk Tidsskrift-Danish Journal of Geography 112, no. 2, 206-207, 2012.

Hacking, I. (2006). Making Up People. London Review of Books. 28(16): 17 August 2006.

"Historia." Internet Website: Samer.se. Last modified September 23, 2019. URL: https:// www.samer.se/historia.

Huntington, Samuel P. “The Clash of Civilizations?” Foreign Affairs 72, no. 3: 22-49, 1993.

Hutton, Chris, Adrian Pablé, and David Bade. "Roy Harris and integrational linguistics." Language Sciences 33, no. 4, 475-479, 2011.

Hutton, Christopher. Linguistics and the Third Reich: Mother-tongue Fascism, Race and the Science of Language. London: Routledge, 1999.

Jan Sahas. Voices of the Invisible Citizens: A Rapid Assessment on the Impact of COVID-19 Lockdown on Internal Migrant Workers. New Delhi. 2020.

Rudolph, Joseph. Politics and Ethnicity: A Comparative Study. Basingstoke: Springer, 2006.

Kaldor, Mary. "In Defence of New Wars." Stability: International Journal of Security and Development 2, no. 1, 4, 2013.

Linell, Per. Rethinking language, mind andworld dialogically. Interactional and contextual theories of human sense-making. Charlotte, NC: Information Age Publishing, 2009.

Lotman Yuri Mikhailovich. On the semiosphere. Trans. Clark W. $\Sigma \eta \mu \varepsilon \iota \omega \tau \iota x \eta ́$ : Sign Systems Studies 33(1): 205-229. (First published in 1984: O semiosfere. Trudy po

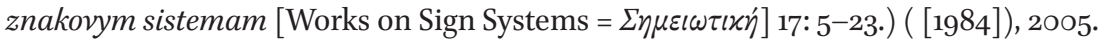

Lotman Yuri Mikhailovich. Universe of the Mind: A Semiotic Theory of Culture, trans. Shukman A. Bloomington, IN: Indiana University Press. [Russian: Vnutri mysljaščich mirov. In: Lotman Y, Semiosfera. Saint Petersburg, 200o, pp. 150-39o.], 1990.

Maher, Kiara. "Historic Court Ruling Upholds Sami Rights in Sweden." Cultural Survival. Last modified February 14, 2020.

Makoni, Sinfree B. "Sociolinguistics, colonial and postcolonial: an integrationist perspective." Language Sciences 33, no. 4, 680-688, 2011. 
Maldonado-Torres, Nelson. "Thinking through the Decolonial Turn: Postcontinental Interventions in Theory, Philosophy, and Critique - An Introduction." Transmodernity: Journal of Peripheral Cultural Production of the Luso-Hispanic World, 1(2), 1-15, 2011.

MacKenzie, John, M. General Editor's Introduction. 20o9. In Chester, Lucy. Borders and conflict in South Asia. The Radcliffe boundary commission and the partition of Punjab. ix-x. Manchester: Manchester University Press.

McGarry, John. "Demographic engineering': the state-directed movement of ethnic groups as a technique of conflict regulation." Ethnic and Racial Studies 21, no. 4, 613-638. doi:10.108o/o14198798329793, 1998.

Mignolo, Walter D. "Epistemic Disobedience, Independent Thought and Decolonial Freedom." Theory, Culture \& Society 26, no. 7-8, 159-181, 2009.

Mukherjee, Kunal. "Insurgency and Peace Building in the Northeast Indian State of Manipur." Democracy and Security 13, no. 3, 220-245, 2017.

Ministry of Home Affairs, Government of India, 2002. Flag code of India. Accessed July 11, 2020. URL: https://knowindia.gov.in/assets/doc/flagcodeofindia_070214.pdf. Ministry of Information and Broadcasting, Government of Pakistan, 2009. Pakistan Flag. Accessed July 11, 2020. URL: https://web.archive.org/web/20090305050001/ http://www.infopak.gov.pk/Flag.aspx.

Misra, Udayon. The Naga conflict: Towards Resolution. In Kumar, Arvind \& Kumar, Radha (eds.), Negotiating Peace in Deeply Divided Societies: A Set of Simulations (New Delhi: Sage Publications, 20o9). In: India Quarterly: A Journal of International Affairs 66, no. 2, 230-233, 2010.

Moral, Radhika. "Peoplehood Beyond the State: Rebellion in a South Asian Borderland." CLAMANTIS: The MALS Journal: Vol. 1: Issue 4, Article 8, 2018.

Nair, S. (2020). Interview Santosh Mehrotra on Reverse migration to villages. The Hindu. 25 May 2020.

Pandey, Gyanendra. Introduction: the difference of subalternity, 1st ed. London: Routledge, 2011.

Pattathu, Antony \& Barnett-Naghshineh, Olivia (2020). Decolonising the classroom Being and becoming 'European Others'. Paper presented at EASA 2020, 21-24 July 2020. URL: https://easaonline.org/conferences/easa2020/.

"1947 Pre-partition India: Radcliffe Award \& Punjab," Europe Solidaire Sans Frontières (ESS) - English, last modified August 17, 2012, Accessed July 11, 2020. URL: https:// www.europe-solidaire.org/spip.php?article26113.

Robb, Peter. "The Colonial State and Constructions of Indian Identity: An Example on the Northeast Frontier in the 188os". Modern Asian Studies, 31(2), (1997) 245-283.

Säljö, Roger. "Digital tools and challenges to institutional traditions of learning: technologies, social memory and the performative nature of learning." Journal of Computer Assisted Learning 26, no. 1, 53-64, 2010. 
Savransky, Martin. "A Decolonial Imagination: Sociology, Anthropology and the Politics of Reality." Sociology 51, no. 1, 11-26, 2017.

Shimrah, Kharingyo. Shared Sovereignty between Indian and Nagalim. The Sangai Express. March 4, 2016. URL: http://www.e-pao.net/epSubPageExtractor. asp?src=news_section.Naga_Peace_Process_Indo-Naga_Talks_2012. Shared_Sovereignty_between_India_and_Nagalim_By_Kharingyo_Henry_Shimrah. Steinkopf-Frank, Hannah. "Urban Exodus? First Signs Of A Move Out Of The World's Cities." Worldcrunch. June 8, 2020.

Svensson, Tom. Ethnicity and Mobilization in SámiPolitics. Stockholm Studies in Social Anthropology Nr 4. Stockholm: Stockholm University, 1976.

The Decolonial Atlas. "The Age of Borders: Most Boundaries Barely A Century Old." The Decolonial Atlas. Last modified January 17, 2018. Accessed 23 July. 2020. URL: https://decolonialatlas.wordpress.com/2018/01/15/ the-age-of-borders-most-boundaries-barely-a-century-old/.

Unrepresented Nations \& Peoples Organization. "Nagalim. " UNPO. April 26, 2019. Accessed July 11, 2020. URL: https://unpo.org/members/7899, 2019.

Vygotsky, L. (1934/1962). Thought and Language. Cambridge: Harvard University Press. Wertsch, James. Mind as action. New York: Oxford University Press, 1998.

Winichakul, Thongchai. Siam Mapped: A History of the Geo-Body of a Nation. Honolulu: University of Hawaii Press, 1994.

White Paper on Naga Integration, Hekhevi Achumi, Secretary (Finance), Naga Hoho: Nagaland, 2002.

Worldometer. "India Population (2020)." Worldometer - Real Time World Statistics. Accessed July 22, 2020. URL: https://www.worldometers.info/world-population/ india-population/. 


\section{Annexure}

\section{Non-linear, overlapping: First and second waves}

First wave: anticolonial, postcolonial, decolonial

SWaSP
Illustrated by...

(a) anticolonial movements like the 1857 Indian Sepoy Mutiny; Gandhi's (1929) non-violent resistance (ahimsa), Satyagraha and Hind Swaraj;

(b) postcolonial thinking by intellectuals like Bhabha who address concepts like nation, narration, and location of culture; Said who tackles imperialism and orientalism and culture; and Spivak who deconstructs hybridity, mimicry, and the other;

(c) black American anticolonial thinking and South African antiapartheid activism that focuses on urban and rural revitalisation programs, attempts at wealth redistribution, and implementation of welfare state bureaucracies;

(d) Afro-Asian Solidarity (1955) at Bandung; the Non-Aligned Movement (1961) forum of nations from the global-South; the Havana Declaration of 1979 ;

(e) 20th century anticolonial movements against cultural and economic dependency that critiques global capitalism; writings that contribute to decolonial framings and Marxist offerings across spaces (e.g. Cusicanqui, Dussel, Gandhi, Gramsci, Grosfoguel, Lenin, Mao, Mignolo, Trotsky and Irish revolutionaries).

Some salient tenets:

- a mobile scholarly gaze that is reflexive;

- encouraging scholarly positionalities as mobile gazing from border spaces;

- acknowledging the non-universalizing multiversal nature of knowledges;

- focusing complexity and heterogenous entanglements, rather than authentic, homogenous ontologies;

- aligning with non-programmatic theories and methodologies that have a democratic basis;

- seeking global-centric epistemic understandings;

- recognizing that marginalized and marginalizing peoples, communities, scholarly gazing exist across times and spaces;

- acknowledging the existence of global-South spaces in the globalNorth and global-North spaces in the global-South;

- expanding colonial marginalizations to include peoples and places marked by the economically disadvantaged, functionally othered, the minoritized, the racialized, etc.

- cultivating a problematizing undisciplinary gaze from cross/inter/multi/ transdisciplinary spaces to break the taken-for-grantedness of a rooted gaze from a given naturalized disciplinary stance;

- troubling single grand narratives;

- recognizing that human mobility, including digitalization, constitute significant dimensions that dissolve hegemonies of place;

- explicating scholars' mobility-marked positionalities beyond their physical situatedness.

FIGURE 8 An overview of First and Second waves 